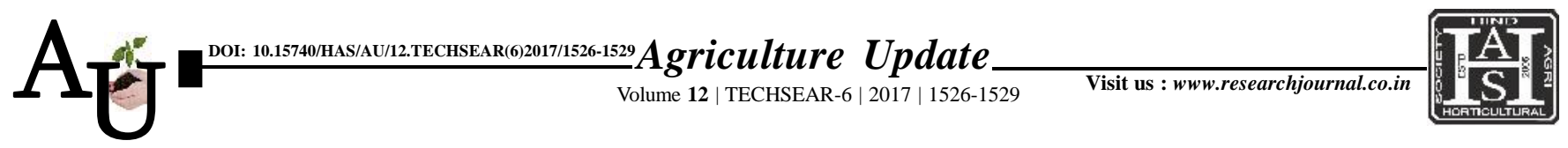

\title{
Research Article: Study on awareness utilization and constraints of farm women in drudgery reducing farm tools in Khammam district Telangana state
}

\author{
E. JYOSHNA, J. HEMANTHA KUMAR, N. KISHORE KUMAR AND \\ P. RAGHURAMI REDDY
}

Article Chronicle: Received : 17.07.2017;

Accepted :

01.08 .2017

KeY Words:

Drudgery, Improved tools, Farm women, Activities, Awareness, constraints

Author for correspondence :

\section{E. JYOSHNA}

KrishiVigyan Kendra,

Wyra, Khammam (TELANGANA) INDIA

See end of the article for authors' affiliations
SUMMARY : The present study is exploratory study to assess the awareness level of farm women on drudgery reducing farm tools. The study was conducted in Khammam district Telangana state. A sample of 100 farm women were interviewed with self developed questionnaire to understand the activities, awareness and barriers towards the usage of improved tools. The results showed that most of the farm women are engaged in tedious farm work and their awareness levels about the improved tools to reduce the work was very less. Lack of availability of information about these tools and lack of training in utilizing the improved tools are perceived as barriers.

How to cite this article : Jyoshna, E., Kumar, J. Hemantha, Kumar, N. Kishore and Reddy, P. Raghurami (2017). Study on awareness utilization and constraints of farm women in drudgery reducing farm tools in Khammam district Telangana state. Agric. Update, 12(TECHSEAR-6) : 1526-1529; DOI: 10.15740/HAS/AU/ 12.TECHSEAR(6)2017/1526-1529. 